\title{
INFLUENCE OF THE HYDRAULIC EXCAVATOR LOCATION WITH A BACKHOE IN THE FACE ON THE EFFICIENCY OF ROCK MASS EXCAVATION
}

\section{O. Frolov, M. Beltek}

National Technical University of Ukraine «Igor Sikorsky Kyiv Polytechnic Institute»

ORCID: 0000-0001-8053-2653; 0000-0002-8048-0635

Purpose. The well-known technological schemes for the development of overburden and production benches in open pit mines for the extraction of soft rocks are analyzed. It is noted that each scheme is characterized by certain parameters of mining operations, which are set taking into account specific mining and geological conditions, the requirements for optimality of mining and transport equipment, and safety. Methodology. To solve the problem, a comprehensive research method was used, which consists in the analysis of previous work on the research of the influence of the location of excavation and loading equipment in the face on the efficiency of its operation and analytical substantiation of the influence of the spatial arrangement of the excavator on its performance. Results. It is recommended to use hydraulic excavators of the «backhoe» type for open pit mining of soft rock deposits according to one of the three existing technological schemes, depending on the mining and geological conditions of mining. The influence of the excavation and loading equipment location relative to the face on its productivity and the completeness of the rock mass is shown. Originality. The interrelation of technological parameters of hydraulic excavators of the «backhoe» type with the prism of a shortage of minerals, which remains in the bottom of the ledge excavation, has been established. The graphical dependence of the technical performance of the excavator on the angle of its rotation for unloading is obtained. Practical value. It was found that with an increase in the angle of rotation of a hydraulic excavator with a backhoe for unloading from $30^{\circ}$ to $180^{\circ}$, its productivity decreases by 2.0 times regardless of the dump truck location below the standing level or at the standing level. In general, the productivity of the excavating and loading equipment when unloading it into a dump truck, which is located below the level of the excavator, is $9.7 \%$ more than when the dump truck is located at the level of the excavator. References 12, tables 1, figures 3.

Key words: technological scheme, quarry, excavator, bench, rock, productivity, face.

\section{ВПЛИВ МІСЦЯ РОЗМІЩЕННЯ ГІДРАВЛІЧНОГО ЕКСКАВАТОРА ЗІ ЗВОРОТНОЮ ЛОПАТОЮ У ВИБОЇ НА ЕФЕКТИВНІСТЬ ВИЙМАННЯ ГІРНИЧОЇ МАСИ}

\section{О. О. Фролов, М. І. Бельтек}

Національний технічний університет України «КПІ ім. Ігоря Сікорського»

\section{ORCID: 0000-0001-8053-2653; 0000-0002-8048-0635}

Проаналізовано відомі технологічні схеми відпрацювання розкривних і видобувних уступів на кар'єрах з видобутку м'яких гірських порід. Зазначено, що кожна схема характеризується певними параметрами гірничих робіт, які встановлюються з урахуванням конкретних гірничо-геологічних умов, вимог оптимальності гірського і транспортного устаткування, забезпечення безпеки. Для вирішення поставленого завдання використано комплексний метод наукових досліджень, який складається в аналізі попередніх робіт по вивченню впливу місця розміщення виймальних-навантажувального обладнання в забої на ефективність його роботи та аналітичного обгрунтування впливу просторового розміщення екскаватора на його продуктивність. Рекомендовано застосовувати гідравлічні екскаватори по одній з трьох існуючих технологічних схем залежно від гірничо-геологічних умов відпрацювання. Показано вплив місця розміщення виймальних-навантажувального обладнання відносно забою на його продуктивність і повноту виймання гірничої маси. Встановлено взаємозв'язок технологічних параметрів гідравлічних екскаваторів типу «зворотна лопата» і існуванням призми недобору корисних копалин, яка залишається в підошві уступу. Отримана графічна залежність технічної продуктивності екскаватора від кута повороту його під розвантаження. Встановлено, що зі збільшенням кута повороту гідравлічного екскаватора зі зворотною лопатою під розвантаження з $30^{\circ}$ до $180^{\circ}$ продуктивність його знижується в 2 рази незалежно від місця розміщення автосамоскида - нижче рівня стояння або на рівні стояння. В цілому ж продуктивність виймальних-навантажувального обладнання при його розвантаженні в автосамоскид, який розміщений нижче рівня стояння екскаватора, більше на 9,7\%, ніж при розташуванні автосамоскида на рівні стояння екскаватора.

Ключові слова: технологічна схема, кар'єр, екскаватор, уступ, порода, продуктивність, забій.

PROBLEM STATEMENT.The diversity of excavation and loading equipment and vehicles used for different mining and geological conditions necessitates the improvement of technological schemes for conducting mining operations in open pits. Improvement of technological schemes for working out benches in open pits and improving the technical and economic indicators of the operation of mining enterprises are possible on the basis of optimizing the parameters and elements of development systems, as well as qualitative and quantitative indicators of mining and loading equipment for various mining conditions of field development. In many open pit mines for the development of soft rocks, in particular kaolin, the technological schemes are outdated. Therefore, the choice of effective technological schemes for the development of ledges is relevant.

Excavation is considered the main technological process in open pit mining. The operating costs of exca- 
vation and loading operations have a significant share in the total development costs. Therefore, ensuring the specified performance of excavators contributes to an increase in the efficiency of opencast mining in general $[1,2]$.

Usually, excavators with "forward" or "back shovel" are used as the main excavation and loading equipment. Typical technological schemes using various types of transport are drawn up for the most common types of excavators. Each scheme is characterized by certain parameters of mining operations, which are set taking into account specific mining and geological conditions, the requirements for optimality of mining and transport equipment, and safety.

In recent years, hydraulic excavators are gradually replacing mechanical excavators and wheel loaders in many types of operations. In particular, in 1970 the share of hydraulic excavators in the total world volume of excavation work was $15,7 \%$, and in 1990 it was already $64,3 \%$. This is due to their advantages in comparison with other excavating and loading machines [3].

Single-bucket hydraulic excavators have high digging forces, great opportunities for selective excavation and can clean the bottom of the face on their own. The higher technical performance of hydraulic excavators is achieved by reducing the digging cycle times. In addition, hydraulic excavators differ from mechanical ones in greater compactness and, in some cases, have better performance indicators [4].

Hydraulic excavators with "back shovels" have become widespread, which have a number of advantages over mechanical shovels, namely: their digging efforts are 1,5 times higher; the weight and cost of the excavator is 1,8-2,5 times less; performance under certain conditions is higher [5]. These advantages, as well as increased power characteristics and the ability to develop rock mass in the face with shavings $0,27 \ldots 0,3 \mathrm{~m}$ thick, determine the technical and economic feasibility of using excavators of the "backhoe" type for selective mining of thin layers of minerals. At the same time, losses of minerals in the process of mining can be reduced due to the absence of a process of preliminary drilling and blasting loosening of the rock mass [6].

In connection with the current global trend towards low-waste resource-saving technologies for the development of deposits in an open way, the task of involving low-power and complex layers of minerals, which are most appropriate to develop reverse hydraulic excavators [6].

In addition, reverse hydraulic excavators have the following advantages:

a) independence of rotation of the bucket handle and boom of the excavator;

b) moving the bucket on any trajectory in the working area and the ability to perform removal at any point along the height of the face;

c) improving the conditions for loading rock mass into vehicles; d) reduction of unit costs for maintenance and repair of mining equipment, reduction of energy consumption and cost of excavation of rocks [5].

Based on the analysis of literary sources, the goal of the scientific research presented below is formulated, namely, to establish the influence of the spatial arrangement of a hydraulic excavator of the "backhoe" type relative to the bottom of the bench on the performance of equipment when excavating rock mass.

MATERIAL AND RESULTS. The main advantage of hydraulic excavators of the "backhoe" type is the possibility of using several types of technological schemes for working out benches (Fig. 1). The most widespread are 3 main schemes. In the 1 st scheme, the excavators are located on the roof of the ledge and remove the rock by bottom digging. When working according to the 2nd scheme, the excavator is located on the lower platform of the ledge, the bucket is filled with upper digging. With the 3rd combined scheme, the excavator is located on the sub-step, combining the advantages of upper and lower digging [7].

The "backhoe" located on the upper platform of the bench can make a rectangular cut (with vertical walls) or wedge-shaped, which makes it possible to reduce the loss of minerals as a result of mining steep $\left(75-90^{\circ}\right)$ seams without leaving under-production prisms [8].

The hydraulic excavator with a backhoe can also (with the receding stroke) remove the layers in the direction from top to bottom, forming a slope of the face from a flat to a vertical or (if necessary) stepped shape. From the point of view of reducing the shedding of minerals from the slope and clogging it with waste rock, this is important in selective excavation.

It should be borne in mind that the conditions for filling the bucket during bottom and top digging are different. During upper digging, the rock, due to the penetration of the cutting tool, is partially moved by the bucket and does not fall into it at the end of the chips. With the bottom scoop, filling the bucket is easier. This is facilitated by the support of rocks during the entire cut of the chips. With bottom digging, the bucket fill ratio will be higher, and the penetration length of the cutting elements to fill the bucket is less than with top digging [8].

Figure 2 shows graphs of changes in the normative losses of minerals for inclined and steep deposits during the operation of extraction machines with upper and lower scooping depending on the angle of incidence of the formation $\beta>9^{\circ}$ (calculations performed for a formation with a thickness of $5 \mathrm{~m}$ ).

From Fig.2 it is seen that the use for extraction of rock mass with hydraulic return shovels at the lower scoop at angles of rotation $45-55^{\circ}$ will reduce mineral losses from $10-19$ to $8-12 \%$. 

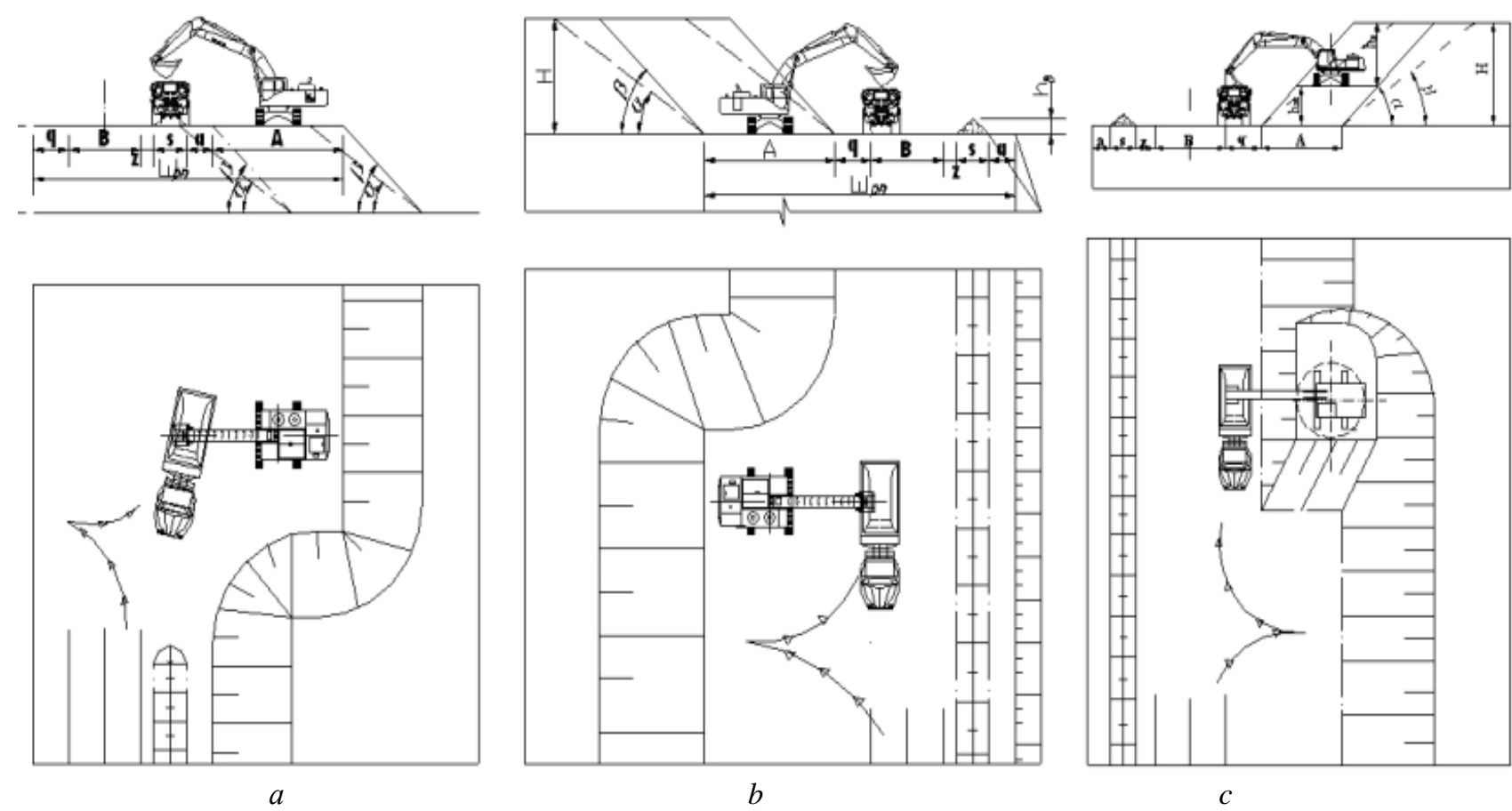

Figure 1 -Technological schemes of operation of hydraulic excavators with a backhoe: a - bottom digging; $b$ - upper digging; c - combined scooping

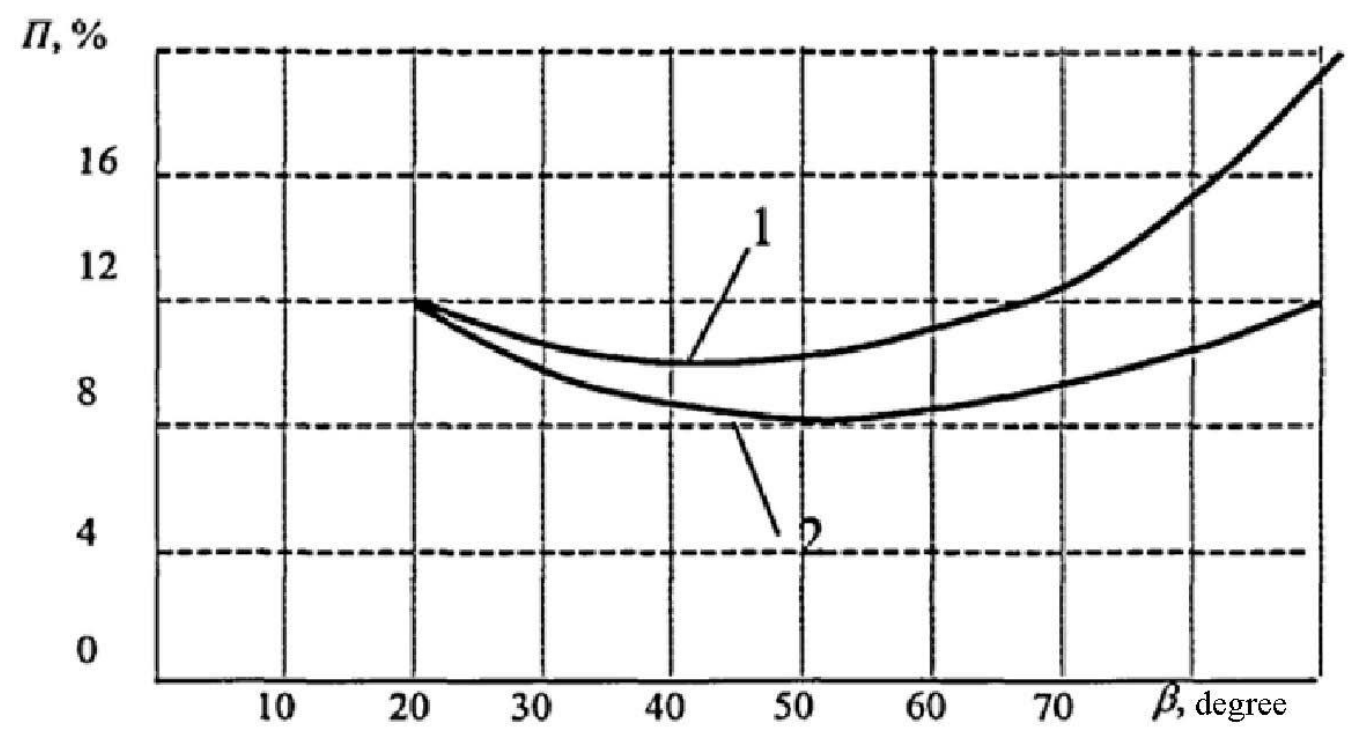

Figure 2 - Graph of the dependence of changes in the normative losses of minerals for inclined and steeply falling fields, worked by hydraulic excavators with upper (1) and lower (2) scooping from the angle of incidence of the formation $\beta$

Also, a fairly wide range of technological capabilities of hydraulic excavators with a backhoe allows them to work without leaving undershoot prisms in the bottom of the excavation and thereby reducing operational losses of minerals [7]. In particular, at stable slope angles of $30^{\circ}$, the working area of the Volvo EC 460 excavator is fully utilized at a bench height of 2,5 m. With a bench height of $5 \mathrm{~m}$, the use of the Volvo EC 460 working area is incomplete, since the undermining prism remains during mining (Fig. 3).
The technical performance of the hydraulic excavator is [9]:

$$
Q_{t}=\frac{3600 E}{t_{c}} k_{e} k_{s}
$$

where $E$ - is the excavator bucket capacity (for Volvo EC460BLC $\left.E=2,1 \mathrm{~m}^{3}\right) ; t_{c}$ - passport duration of the excavation cycle, $t_{c}=15 \mathrm{c} ; k_{s}$ - bottomhole parameters influence coefficient; $k_{e}$ - excavation ratio [10]: 


$$
k_{e}=\frac{k_{b f}}{k_{l}},
$$

where $k_{b f}$ - bucket filling ratio, $k_{b f}=1 ; k_{l}$ - coefficient of loosening of rock mass in a ladle, $k_{l}=1,2$.

$$
k_{s}=k_{h} \cdot k_{\alpha} \cdot k_{r} \cdot k_{k} \text {, }
$$

where $k_{h}$ - coefficient taking into account the effect of bottomhole height on bucket filling, $k_{h}=0,95 ; k_{\alpha}-$ coefficient taking into account the influence of the angle of rotation of the excavator on unloading; $k_{r}$ - coefficient taking into account the conditions of loading the rock into transport; $k_{k}$ - coefficient taking into account the qualifications of the excavator driver, $k_{k}=0,85$.

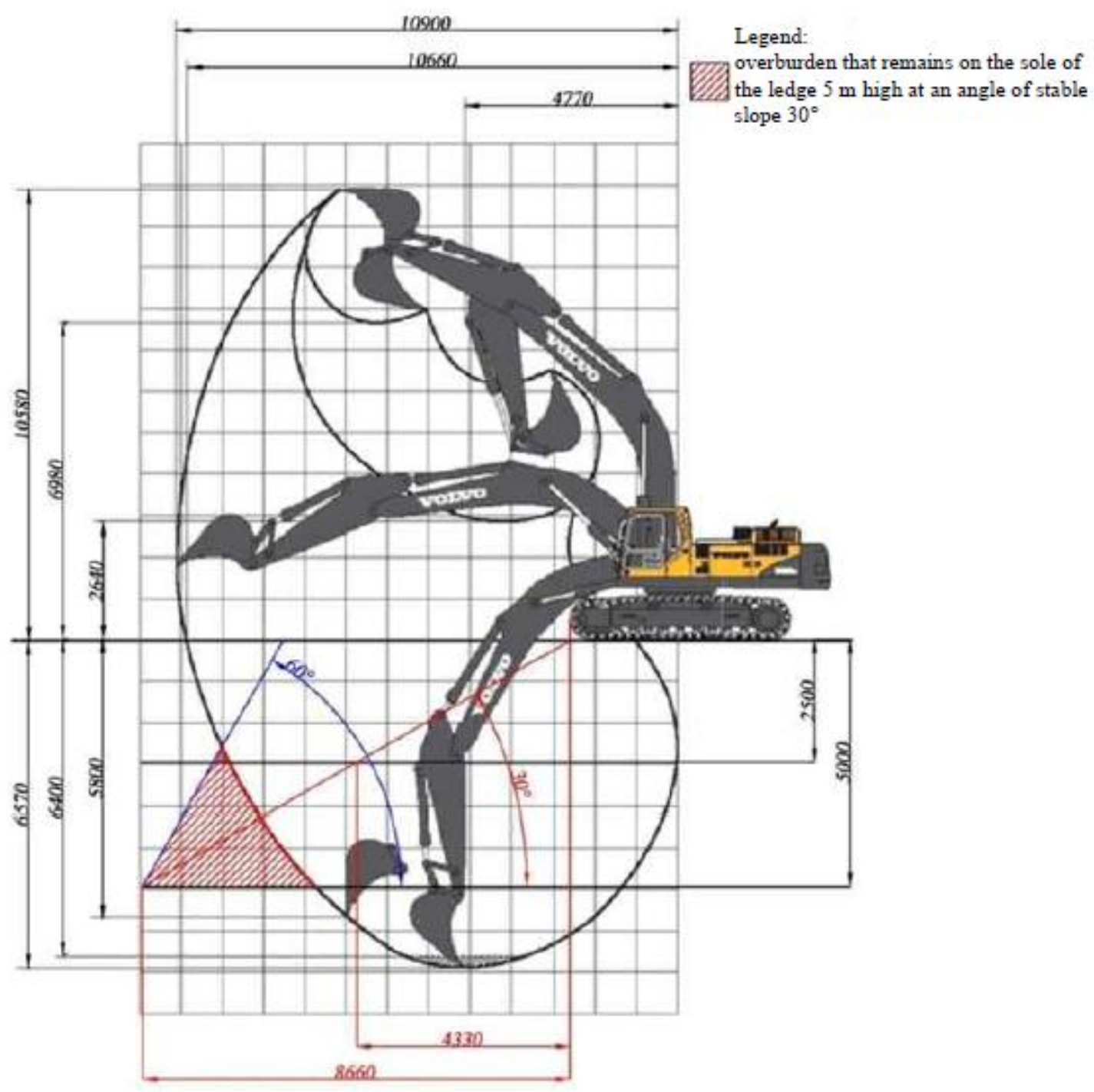

Figure 3 -Diagram of the use of the working area of the Volvo EC 460 excavator when mining soft rocks with a bench height of $5 \mathrm{~m}$

As you can see, the technical performance directly depends on the spatial arrangement of the excavator in the mining flow chart. In particular, from the location of the excavator in the face, the angle of its rotation changes when loaded into the transport (Table 1).

Table 1-Dependence of the coefficient $\mathrm{k}_{\alpha}$ on the angle of rotation of the excavator for unloading into transport [11]

\begin{tabular}{|c|c|c|c|c|c|c|}
\hline Excavator swing angle for unloading, degrees & 30 & 60 & 90 & 120 & 150 & 180 \\
\hline$k_{\alpha}$ & 1,4 & 1,2 & 1,0 & 0,9 & 0,8 & 0,7 \\
\hline
\end{tabular}

The location of the dump truck is determined by a coefficient that takes into account the conditions for loading rocks into vehicles $\mathrm{kr}$. When loading rock mass with an excavator into a vehicle that is located below the level of its standing $-k_{r}=2,88$. For vehicles located at the level of the excavator this coefficient is $k_{r}=2,65$ [10]. 
For all possible options for the spatial arrangement of the excavator relative to the transport, a graph of the dependence of the technical performance of the exca- vator on the angle of its rotation for unloading is built (Fig. 4) [12].

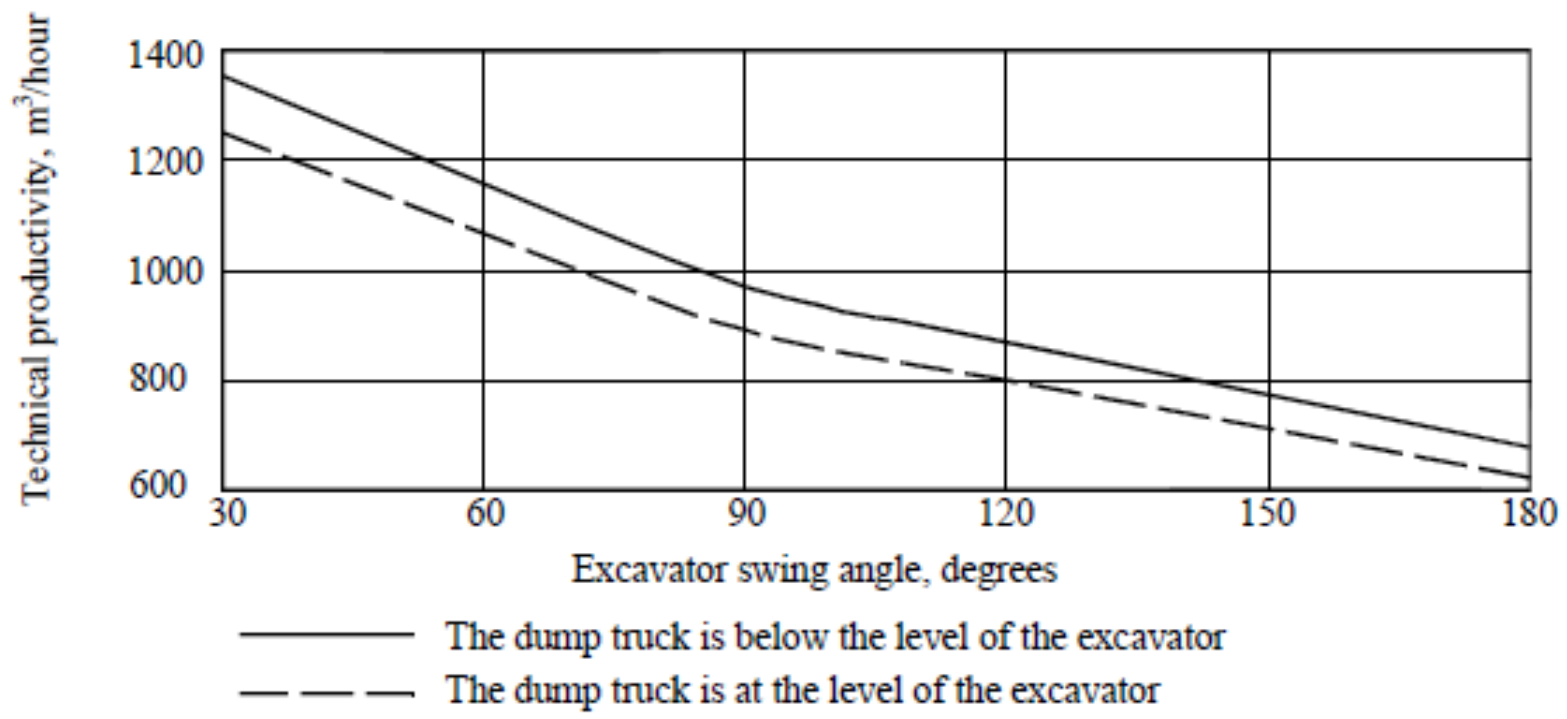

Figure 4 - Dependence of excavator productivity on its swing angle for unloading

Analysis of Fig. 3 shows that with an increase in the swing angle of the excavator, its productivity decreases. It can also be seen from the graph that productivity is higher for the case of placing the dump truck below the excavator's standing level.

Also, for the above technological schemes of operation of a hydraulic excavator with a backhoe, the calculation of motor transport was performed by setting the number of auto-tons of rock mass per dump truck.
The calculation of the number of auto-tones is carried out for two schemes of feeding the dump truck into the face: according to the dead-end scheme and the loop scheme.

Based on the results of calculations of the number of auto-tons per dump truck for loop and dead-end schemes on overburden and on mineral, a diagram was constructed (Fig. 5).

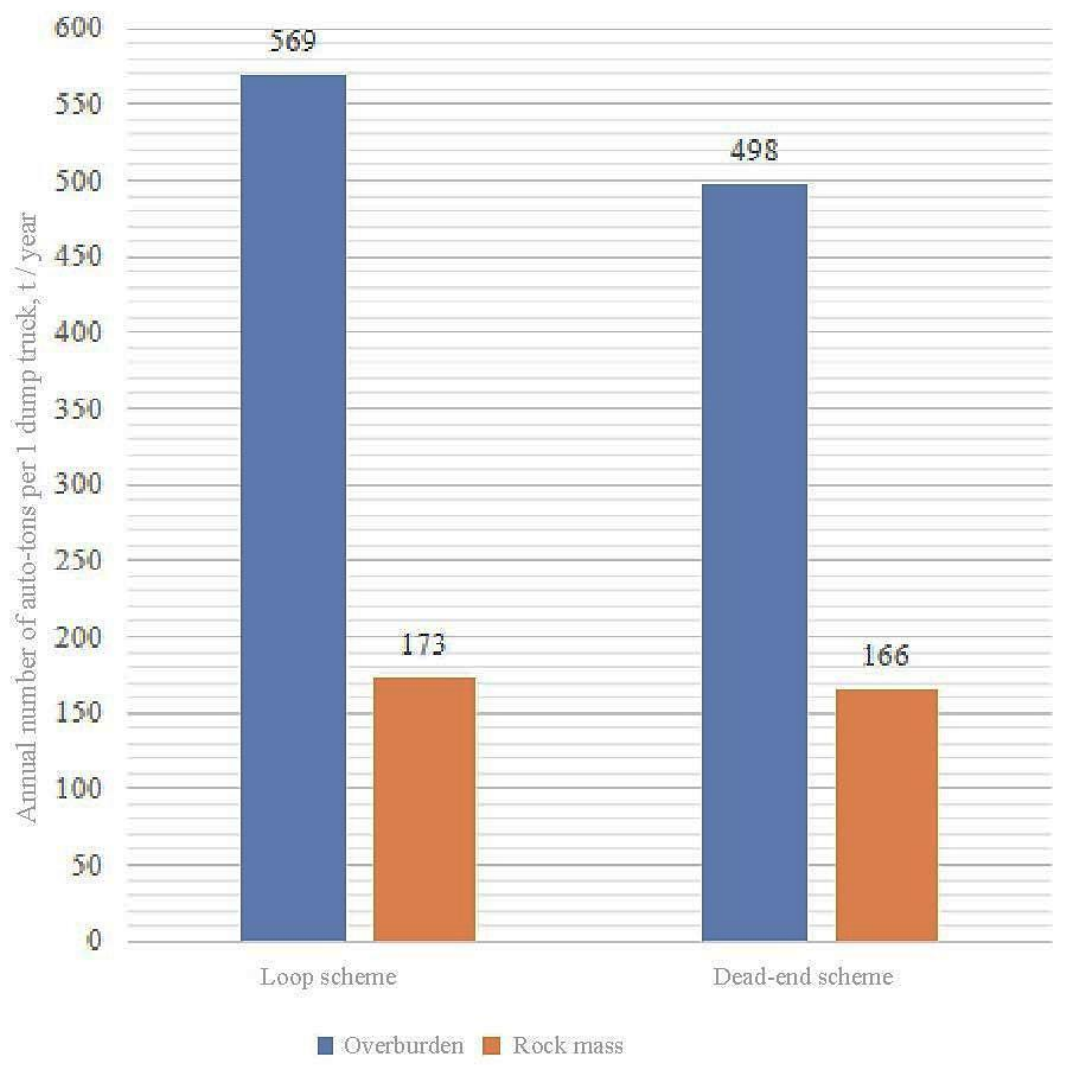

Figure 5 - Estimated number of auto-tons for a dump truck according to the approach for loading 
The analysis of the obtained results shows that the efficiency of technological schemes in which the supply of the dump truck is on the loop scheme is higher than in the dead-end scheme, because the annual number of auto-tones per dump truck is greater in the loop scheme in $1,04 \ldots 1,14$ times compared to the dead-end scheme. [12].

CONCLUSIONS. Thus, it was established that, despite scientific research in this direction, the issues of rational spatial arrangement of equipment in the technological scheme remain relevant. One of the advantages of using technological schemes with the use of a backhoe excavator is the possibility of placing it at different levels relative to the face height.

It was found that with an increase in the swing angle of a hydraulic excavator of the "backhoe" type from $30^{\circ}$ to $180^{\circ}$, its productivity decreases from 1360 to $680 \mathrm{~m}^{3} / \mathrm{h}$ when the dump truck is located below the standing level and from 1240 to $620 \mathrm{~m}^{3} / \mathrm{h}$ when the dump truck is located at the standing level, i.e. 2 times. In general, the productivity of the excavator is $9,7 \%$ higher when the dump truck is lower than the standing level of the excavator than when it is located at the standing level.

\section{REFERENCES}

1. Tipovye tekhnologicheskie skhemy vedeniya gornyh rabot na ugol'nyh razrezah (1982). Ministerstvo ugol'noj promyshlennosti SSSR. Moskva: Nedra.

2. Krjuchkov, A., Jevtjejeva, L. (2014). “Optymizacija produktyvnosti ekskavatoriv na kar'jeri za kryterijem energojemnos", Suchasny resursoenergozberigauchi tehnolohii hirnychoho vyrobnytstva. Kremenchuk Mikhailo Ostrohradskyi National University, vol. 1, no. 13, pp. 97-103.

3. Anistratov, K. Yu. (2011). "Mirovye tendencii razvitiya struktury parka kar'ernoj tekhniki”, Gornaya promyshlennost', № 26, pp. 22-26.

4. Kantovich, L. I., Litvin, O. I., Horeshok, A. A., Tyuleneva, E. A. (2019). “Opyt i perspektivy primeneniya gidravlicheskih ekskavatorov pri otrabotke uglenasyshchennyh zon na razrezah Kuzbassa", Gornyj informacionno-analiticheskij byulleten', № 4, pp. 152160.

5. Loginov, E. V. (2016). “Osobennosti primeneniya gidravlicheskih ekskavatorov tipa obratnaya lopata", Nauchnyj zhurnal, № 6, pp. 152-154.

6. Kosenko, N. V., Golubnichij, D. V., Le Dyk Fyong (2002). "Osnovnye preimushchestva gidravlicheskih ekskavatorov po sravneniyu s mekhanicheskimi lopatami”, Problemy mashinovedeniya $i$ mashinostroeniya, № 28, pp. 27-32.

7. Logvinov, E. V. (2017). "Umen'shenie ekspluatacionnogo koefficienta vskryshi pri ispol'zovanii gidravlicheskih ekskavatorom", Gornyj informacionno-analiticheskij byulleten', № 4, pp. 108115 .

8. Kosenko, N. V. (2003). "Selektivnaya razrabotka plastov s pomoshch'yu gidrav-licheskih ekskavatorov tipa obratnaya lopata". Problemy mashinovedeniya $i$ mashinostroeniya, № 29, pp. 20-24.

9. Macak, B. V. (2000). "Opredelenie proizvoditel'nosti ekskavatorov pri razrabotke slozhnostrukturnyh gorizontal'nyh plastov uglya. Gornyj informacionno".-analiticheskij byulleten', № 8, pp. 3233.

10. Buyanov, Yu. D., Krasnopol'skij, A. A. (1980). "Razrabotka mestorozhdenij nerudnyh poleznyh iskopaemyh", Moskva: Nedra.

11. SOU-N MPP 73.020-078-1 (2007). "Normy tekhnolohichnoho proektuvannia hirnychodobuvnykh pidpryiemstv iz vidkrytym sposobom rozrobky rodovyshch korysnykh kopalyn", Chastyna 1. Kyiv

12. Beltek, M.I. (2019). "Obhruntuvannia tekhnolohichnykh skhem vidpratsiuvannia rozkryvnykh ta vydobuvnykh ustupiv karieru Viknynskoho rodovyshcha", II naukovo-tekhnichna konferentsiia mahistrantiv IEE, KPI im. Ihoria Sikorskoho, Kyiv. 